https://doi.org/10.46344/JBINO.2020.v09i03.13

\title{
NEW WAYS TO LOOK AT NUTRACEUTICALS (Research Article)
}

\section{Nusratullah Khan'., Shah Murad'2., Shumaila Najeeb³., Saleemullah Abro4., Altaf H Mahar5., Abdul Ghaffar ${ }^{6}$ \& Seema Saif ${ }^{7}$}

1,Assistant Prof of Biochemistry at Bolan University of Medical and health Sciences, Quetta, Pakistan

2.Professor of Therapeutics at IMDC, Islamabad-PAKISTAN.

3.Asso Prof of Histopathology at Yusra Medical College, Islamabad Pakistan

4.AP Physiology at Baqai Medical University Karachi Pakistan

5.Rese Scholar at HEJ Institute, KU Pakistan

6.CWO at IMDC/DANTH Isd Pakistan

7. Gynaecologist at NMC Karachi Pakistan.

\section{ABSTRACT}

In children, a high level of $\mathrm{Lp}(\mathrm{a})$ is a leading risk factor for strokes but strokes are very rare in any child, even those with a high level of Lp(a). Analysis of the lipid content in the oxidatively modified LDL from hyper lipidemic patients revealed that the level of lysophosphatidylcholine was greatly elevated, and the high level of the lysolipid was shown to impair the endothelium-dependent relaxation of the blood vessels. In allopathy blood lipid levels are normalized by statins, fibrates, niacin and bile acid binding resins (BABRs). All of these allopathy related drugs have low compliance ranges from mild compliance due to metalic taste of BABRs to severe side effects like rhabdomyolysis by fibrates and statins. Cardiovascular diseases are leading cause of death in western and eastern countries of the world. Hyperlipidemia is one of the strong risk fractions for heart diseases. To evaluate hypolipidemic drugs efficacy, the study was conducted at Ghurki trust teaching hospital, Lahore Pakistan from January 2018 to August 2018. Ninty hyperlipidemic patients were selected from cardiology and medical wards of the hospital. They were divided in three groups, one at placebo therapy, another on Kalonji and third one on Vitamin B3. After one and half month, significant changes ( $\mathrm{p}$ value ranging from $<0.05$ to $<0.001$ ) were observed in their LDL and HDL-cholesterol. Conclusion of the study was to recommend use of herbal medicine and vitamin B3 for prevention of any heart diseases with good patient compliance.

Keywords : Nil 


\section{INTRODUCTION}

Due to low compliance and adverse effects of conventionally used hypolipidemic agents, herbal medicines are going to be famous among Physicians, and Cardiologists. Medicinal herbs like Curcuma Longa, Fenugreek, and Lemon contents are being used as mild to moderate hypolipidemic agents. Curcuma Longa commonly known as Haldi in India and Pakistan is used to lower plasma lipids, in view of their contents. It contains Curcuminoids (curcumin, demethoxycurcumin,

and bisdemethoxycurcumin), turmerone, atlantone, zingiberene, proteins, and resins. Coronary artery disease (CAD)occurs when the inside (the lumen) of one or more coronary arteries narrows, limiting the flow of oxygen-rich blood to surrounding heart muscle tissue. Atherosclerosis is the process that causes the artery wall to get thick and stiff. It can lead to complete blockage of the artery, which can cause a heart attack'. The disease process begins when LDL deposits cholesterol in the artery wall. The body has an immune response to protect itself and sends white blood cells called macrophages to engulf the invading cholesterol in the artery wall. When the macrophages are full of cholesterol, they are called foam cellsbecause of their appearance. As more foam cells collect in the artery wall, a fatty streak develops between the intima and the media. If the process is not stopped, the fatty streak becomes a plaque, which pushes the intima into the lumen, narrowing the blood flow ${ }^{2-6}$. Withfew exceptions, low $\mathrm{HDL}$ is an independent risk factor for CAD in casecontrol and prospective observational studies ${ }^{7}$. In contrast, high HDL levels are associated with longevity and are protective against the development of atherosclerotic disease ${ }^{8}$. In the Framingham Study, risk for CAD increases sharply as $\mathrm{HDL}$ levels fall progressively below $40 \mathrm{mg} / \mathrm{dL}^{9-10}$. In the Quebec Cardiovascular Study, for every $10 \%$ reduction in $\mathrm{HDL}$, risk for CAD increased 13\%. ${ }^{2}$ Many clinicians believe that low HDL is associated with increased CAD risk because it is a marker for hypertriglyceridemia and elevated remnant particle concentrations. The Prospective Cardiovascular Münster Study, however, demonstrated that the increased risk associated with low HDL is independent of serum triglyceride levels ${ }^{11}$. There is considerable controversy about whether one HDL subfraction is more antiatherogenic than others. At the present time, the preponderance of evidence favors increasing total HDL mass, rather than any one subfraction of this lipoprotein. In the Framingham Study, risk for CAD increases sharply as HDL levels fall progressively below $40 \mathrm{mg} / \mathrm{dL}^{12}$.

\section{MATERIAL \& METHOD}

The study was conducted at Ghurki trust teaching hospital, Lahore Pakistan from January 2018 to August 2018. Ninty patients 
were selected for study. Consent was taken from all participants. Inclusion criteria was primary and secondary hyperlipidemic patients. Exclusion criteria was patients suffering from any kidney, liver and thyroid related disease. Name, age, gender, occupation, residential address, phone/contact number, previous medical history, disease in family history, drug history were recorded in specific Performa. Three groups I, II, and III were made (30 patients in each group). Group-I was allocated for placebo, to take placebo capsule once daily, after breakfast for six weeks. Group-II was advised to take 2 tea spoons of kalonji after breakfast for the period of six weeks. Group-III was on Niacin 2 grams in divided doses, after breakfast, lunch and dinner for 6 weeks. Their base line LDL-cholesterol and HDL-cholesterol level was estimated at the start of research work. Their serum was taken at follow up visits, fortnightly for lipid profile. Data were expressed as the mean $\pm S D$ and ' $t$ ' test was applied to determine statistical difference in results. A p-value $>0.05$ was considered as nonsignificance and P-value $<0.001$ was considered as highly significant change in the differences. Serum LDL-cholesterol was calculated by formula (LDLCholesterol=Total Cholesterol(Triglycerides/5 +HDL-Cholesterol). Serum HDL-cholesterol was determined by using kit Cat. \# 3022899 by Eli Tech Diagnostic, France

\section{DATA INFERENCE \& RESULTS}

Numerical values and results of all parameters of participated patients were analyzed biostatistically. In placebo group, LDL-cholesterol decreased from $189.15 \pm 3.90 \mathrm{mg} / \mathrm{dl}$ to $186.75 \pm 2.08 \mathrm{mg} / \mathrm{dl}$, change in the parameter is $2.40 \mathrm{mg} / \mathrm{dl}$. This difference in pretreatment and post treatment value is non-significant, ie; Pvalue $>0.05$. HDL-cholesterol in placebo group increased from $36.11 \pm 2.11 \mathrm{mg} / \mathrm{dl}$ to $37.17 \pm 1.51 \mathrm{mg} / \mathrm{dl}$. The difference in parameter was $1.06 \mathrm{mg} / \mathrm{dl}$. Statistically this change in parameter was nonsignificant, ie; P-value $>0.05$. In Nigella sativa group, out of 30 hyperlipidemic patients, 27 patients completed over all study period. LDL-cholesterol in this group decreased from $202.45 \pm 1.54 \mathrm{mg} / \mathrm{dl}$ to $189.52 \pm 2.21 \mathrm{mg} / \mathrm{dl}$. The difference in pretreatment and postreatment mean values is $12.93 \mathrm{mg} / \mathrm{dl}$. Statistically this change in two mean values is highly significant, with $\mathrm{p}$-value $<0.001$. HDLcholesterol in this group increased from $38.81 \pm 3.9042 .19 \pm 3.32 \mathrm{mg} / \mathrm{dl}$. Change in two mean values was $3.38 \mathrm{mg} / \mathrm{dl}$. Statistically this change is significant, with probability value $<0.01$. In group III, 28 patients completed the research. LDL-cholesterol in this group decreased from $212.65 \pm 2.32$ to $185.61 \pm 3.43 \mathrm{mg} / \mathrm{dl}$ in six weeks treatment. Change in pre and post treatment mean values is $27.04 \mathrm{mg} / \mathrm{dl}$. Statistically this change is highly significant, i.e., P-value < 0.001. HDL-cholesterol increased from $39.19 \pm 2.01$ to $43.00 \pm 3.07 \mathrm{mg} / \mathrm{dl}$ in six weeks. Change in two parallel values is $3.49 \mathrm{mg} / \mathrm{dl}$, which is significant with $\mathrm{P}$-value $<0.01$. 
Table: 1

LDL, HDL's basic values (pre and after treatment) and their biostatistical significance

\begin{tabular}{|c|c|c|c|c|}
\hline $\begin{array}{ll}\text { No. } & \text { Of } \\
\text { patients } & \\
\end{array}$ & Day-0 values & Day-45 values & Change in basic values & $\begin{array}{l}\text { Statistical } \\
\text { significance }\end{array}$ \\
\hline $\begin{array}{l}\text { Placebo } \\
\text { (30 pts) }\end{array}$ & $\begin{array}{l}\text { LDL- } \\
c=189.15 \pm 3.90 \\
\text { HDL- } \\
c=36.11 \pm 2.11\end{array}$ & $\begin{array}{l}\mathrm{LDL}=186.75 \pm 2.08 \\
\mathrm{HDL}=37.17 \pm 1.51\end{array}$ & $\begin{array}{l}2.40 \\
1.06\end{array}$ & $\begin{array}{l}>0.05 \\
>0.05\end{array}$ \\
\hline $\begin{array}{l}\text { Kalonji (27 } \\
\text { pts) }\end{array}$ & $\begin{array}{l}\text { LDL- } \\
c=202.45 \pm 1.54 \\
\text { HDL- } \\
c=38.81 \pm 3.90\end{array}$ & $\begin{array}{l}\mathrm{LDL}=189.52 \pm 2.21 \\
\mathrm{HDL}=42.19 \pm 3.32\end{array}$ & $\begin{array}{l}12.93 \\
3.38\end{array}$ & $\begin{array}{l}<0.001 \\
<0.01\end{array}$ \\
\hline $\begin{array}{l}\text { Vit B3 (28 } \\
\text { pts) }\end{array}$ & $\begin{array}{l}\text { LDL- } \\
c=212.65 \pm 2.32 \\
\text { HDL- } \\
c=39.19 \pm 2.01\end{array}$ & $\begin{array}{l}\mathrm{LDL}=185.61 \pm 3.43 \\
\mathrm{HDL}=43.00 \pm 3.07\end{array}$ & $\begin{array}{l}27.04 \\
3.49\end{array}$ & $\begin{array}{l}<0.001 \\
<0.01\end{array}$ \\
\hline
\end{tabular}

KEY: HDL and LDL are measured in $\mathrm{mg} / \mathrm{dl}, \mathrm{n}$ stands for sample size, $\mathrm{p}$-value $>0.05$ indicate non-significant, $<0.01$ indicate significant and $<0.001$ indicate highly significant change in basic values

\section{DISCUSSION}

Cholesterol is produced naturally in your liver because every cell in your body uses it. Similar to triglycerides, cholesterol is also found in fatty foods like eggs, red meat, and cheese. Hyperlipidemia is more commonly known ashigh cholesterol. Although high cholesterol can be inherited, it's more often the result of unhealthy lifestyle choices. Treatment with three weeks, Kalonji decreased LDL-cholesterol $12.93 \mathrm{mg} / \mathrm{dl}$ by six weeks of treatment. HDLcholesterol increased $3.38 \mathrm{mg} / \mathrm{dl}$ by taking this drug for six weeks. The change in both parameters were significant. In placebo group, LDL-C reduction was $2.40 \mathrm{mg} / \mathrm{dl}$ and increase in HDL-C was $1.06 \mathrm{mg} / \mathrm{dl}$ with P-value $>0.05$, which proves non-significant change in results. These results match with Akhondian et all3 who did prove that Nigella sativa is very effective hypolipidemic drug. He tested the drug on 120 hyperlipidemic and diabetic patients by using Nigella sativa for one month. Their results were highly significant when compared with placebo-controlled group. Our results also match with results of Gillani $\mathrm{AH}$ et al ${ }^{14}$ who proved LDL-Cholesterol reduction from $201.61 \pm 3.11 \mathrm{mg} / \mathrm{dl}$ to $187.16 \pm 2.10 \mathrm{mg} / \mathrm{dl}$ in fourty hyperlipidemic patients. Their HDL-C increase was 3.98 $\mathrm{mg} / \mathrm{dl}$ which also matches with our results. Results of our study are in contrast with results of research work conducted by $\mathrm{AH}$ $\mathrm{BH}$ and Blunden $\mathrm{G}^{15}$. They explained that 
some active ingredients of Nigella sativa are hypolipidemic but their hypolipidemic effects are very narrow spectrum. Their results showd only $2.11 \mathrm{mg} / \mathrm{dl}$ change in LDL-C and $0.92 \mathrm{mg} / \mathrm{dl}$ increase in HDL-C of 38 rats. Difference in results may be genetic variants of human and rats. Brown BG et al ${ }^{16}$ also described phenomenon of genetic variation in pharmacological effects of Nigella sativa. Burits $M$ \& Bucar $\mathrm{F}^{17}$ have also mentioned wide variety effects of Nigella sativa with different genetic make ups. Our results also match with results of research work of Dehkordi FR \& Kamkhah $\mathrm{AF}^{18}$ and El-Dakhakhany $\mathrm{M}^{19}$. Same mechanism of action of drug Nigella sativa is described by El-Din $\mathrm{K}$ et al20. In our research Niacin reduced LDL-Cholesterol from $212.65 \pm 1.19 \mathrm{mg} / \mathrm{dl}$ to $185.61 \pm 1.65$ $\mathrm{mg} / \mathrm{dl}$ in six weeks. This reduction in LDL-C was $27.04 \mathrm{mg} / \mathrm{dl}$, which is highly significant change, when analyzed statistically. These results match with resultsn of research work conducted by Afilalo J et al ${ }^{21}$ who proved almost same change in LDL-C in 32 hyperlipidemic patients who were cases of secondary hyperlipidemia and used Niacin 2 grams daily for two months. Their LDL-C reduction was $25.55 \mathrm{mg} / \mathrm{dl}$. Their HDL-C increase was $6.65 \mathrm{mg} / \mathrm{dl}$ in 2 months. In our results $\mathrm{HDL}-\mathrm{C}$ increase was $3.81 \mathrm{mg} / \mathrm{dl}$ in six weeks use of Niacin. Our results also match with results of research conducted by Whitney EJ et al 22 who proved $27.77 \mathrm{mg} / \mathrm{dl}$ reduction in LDL-C in 19 hyperlipidemic patients. Ginsberg $\mathrm{HN}$ et $\mathrm{al}^{23}$ also support our results, as they proved $4.00 \mathrm{mg} / \mathrm{dl}$ increase in HDL-C when two grams of Niacin was used in 34 hyperlipidemic patients for six weeks. Our results do not match with results of research conducted by Boden WE et al24 who proved that 2.5 grams Niacin decreased $10.99 \mathrm{mg} / \mathrm{dl}$ LDLCholesterol. HDL-C increase was only 1.11 $\mathrm{mg} / \mathrm{dl}$. These differences may be considered due to lack of physical exercise and no restriction of use of lipids in their diet. Taylor AJ et al25 used Niacin 1.5 grams in 29 hyperlipidemic patients for 3 weeks. Patients reduced their LDL-C from 189.88 $\pm 1.11 \mathrm{mg} / \mathrm{dl}$ to $187.87 \pm 0.99 \mathrm{mg} / \mathrm{dl}$. Difference in their results and our results is due to less sample size, lesser duration of exposure of patients to drug and small amount of drug given in their patients. Baigent $C$ et $a^{26}$ explained that Niacin inhibits the peripheral mobilization of free fatty acids, which decreases the substrate available for hepatic synthesis of triglycerides and very low-density lipoprotein (VLDL) particles.

\section{REFERENCES}

1. Despres JP, Lemieux I, Dagenais GR, et al. HDL-cholesterol as a marker of coronary heart disease risk: the Quebec cardiovascular study. JMT 2016;1 1(9):90-6.

2. Barter $\mathbf{P}$. The role of $\mathrm{HDL}$-cholesterol in preventing atherosclerotic disease. EJMS 2010;12(8):41-9.

3. Sang ZC, Wang F, Zhou Q, Li YH, Li YG, Wang HP, et al. Combined use of extended-release niacin and atorvastatin: safety and effects on lipid modification. CMJ 2010;1 1 (2):110-6. 
4. Sharrett AR, Ballantyne CM, Coady SA, Heiss G, Sorlie PD, Catellier D, et al. Coronary heart disease prediction from lipoprotein cholesterol levels, triglycerides, lipoprotein(a), apolipoproteins A-I and B, and HDL density subfractions: the Atherosclerosis Risk in Communities (ARIC) Study. Circulation 2001;104:1108-13.

\section{Voight BF, Peloso GM, Orho-Melander M,} Frikke-Schmidt $R$, Barbalic $M$, Jensen $M K$, et al. Plasma HDL cholesterol and risk of myocardial infarction: a mendelian randomization study. Lancet 2012;380:57280.

6. Ridker PM. C-reactive protein: a simple test to help predict risk of heart attack and stroke. Circulation 2003; 108: e81-e85.

7. Weverling-Rijnsburger AWE, Jonkers IJA, van Exel E, et al. High-density vs low-density lipoprotein cholesterol as the risk factor for coronary artery disease and stroke in old age. Arch Intern Med.2003; 163: 15491554.

8. The 'good cholesterol': high-density lipoprotein. Circulation. 2005;1 11 :e89-e91.

9. Toth PP. Reverse cholesterol transport: high-density lipoprotein's magnificent mile. Curr Atheroscler Rep. 2003; 5: 386393.

10. Nofer J, Kehrel B, Fobker M, et al. HDL and arteriosclerosis: beyond reverse cholesterol transport. Atherosclerosis. 2002; 161: 1-16.

11. Nissen SE, Tsunoda T, Tuzcu EM, et al. Effect of recombinant apoA-I Milano on coronary atherosclerosis in patients with acute coronary syndromes: a randomized controlled trial. JAMA 2003; 290: 2292-2300.

12. American Diabetes Association. Management of dyslipidemia in adults with diabetes. Diabetes Care 2003; 26: S83-S86.

\section{Akhondian J, Parsa A, Rakhshande H.} The effect of nigella sativa L. (black cumin seed) on intractable pedi- atric seizures. Med. Sci. Monit. 2007; 13: 555-9.

\section{Gilani AH, Jabeen O, Asad Ullah Khan}

M. A review of medicinal uses and pharmacological activities of Nigella sativa. Pak. J. Biol. Sci. 2004; 7 (4): 441-451.

15. AH BH, Blunden G. Pharmacological and toxicological properties of nigella sativa. Phytother. Res. 2003; 17 (4): 299-305.

16. Brown BG, Zhao XQ, Chait A, et al. Simvastatin and niacin, antioxidant vitamins, or the combination for the prevention of coronary disease. $N$ Engl $J$ Med. 2001; 345: 1583-1592.

17. Burits $\mathbf{M}$, Bucar F. Antioxidant activity of Nigella sati- va essential jeTil. Phytother. Res. 2000; 14 (5): 323-8.

18. Dehkordi FR, Kamkhah AF. Antihypertensive effect of Nigella sativa seed extract in patients with mild hypertension. Fundam. Clin. Pharmacol 2008; 22 (4): 447-52.

19. El-Dakhakhany $M$. Some pharmacological properties of some constituents of nigella sativa seeds: The carbo- nyl fraction of essential oil. Proceedings of the 2nd International 
concerence on Islamic Medicine Kuwait, 1982: 426-31.

20. El-Din K, El-Tahir H, Bakeet DM. The black seed (Ni-gella sativa Linnaeus) - a mine for multi cures: A plea for urgent clinical evaluation of its volatile oil. JTU. Med. Sci. 2006; 1: 1-19.

21. Afilalo J, Majdan AA, Eisenberg MJ. Intensive statin therapy in acute coronary syndromes and stable coronary heart disease: a comparative meta-analysis of randomised controlled trials. Heart 2007:93:914-21.

22. Whitney EJ, Krasuski RA, Personius BE, Michalek JE, Maranian AM, Kolasa MW, et al. A randomized trial of a strategy for increasing high-density lipoprotein cholesterol levels: effects on progression of coronary heart disease and clinical events. Ann Intern Med 2005; 142:95-104.

23. Ginsberg HN, Elam MB, Lovato LC, Crouse JR, Leiter LA, Linz $\mathbf{P}$, et al. Effects of combination lipid therapy in type 2 diabetes mellitus. $N$ Engl J Med 2010;362:1563-74.
24. Boden WE, Probstfield JL, Anderson T, Chaitman BR, Desvignes-Nickens $P$, Koprowicz K, et al. Niacin in patients with low HDL cholesterol levels receiving intensive statin therapy. $N$ Engl J Med 2011;365:2255-67.

25. Taylor AJ, Sullenberger LE, Lee HJ, Lee JK, Grace KA. Arterial Biology for the Investigation of the Treatment Effects of Reducing Cholesterol (ARBITER) 2: a double-blind, placebo-controlled study of extended-release niacin on atherosclerosis progression in secondary prevention patients treated with statins. Circulation 2004;110:3512-7.

\section{Baigent $C$, Keech A, Kearney PM,} Blackwell L, Buck G, Pollicino $\mathrm{C}$, et al. Efficacy and safety of cholesterol-lowering treatment: prospective meta-analysis of data from 90,056 participants in 14 randomised trials of statins. Lancet 2005;366:1267-78. 